\title{
Soil carbon and nitrogen erosion in forested catchments: implications for erosion-induced terrestrial carbon sequestration
}

\author{
E. M. Stacy ${ }^{1}$, S. C. Hart ${ }^{2,3}$, C. T. Hunsaker ${ }^{4}$, D. W. Johnson ${ }^{5}$, and A. A. Berhe ${ }^{2,3}$ \\ ${ }^{1}$ Sierra Nevada Research Institute, University of California, Merced, Merced, CA, USA \\ ${ }^{2}$ Environmental Systems Graduate Group, University of California, Merced, Merced, CA, USA \\ ${ }^{3}$ Life \& Environmental Sciences and the Sierra Nevada Research Institute, University of California, Merced, Merced, CA, \\ USA \\ ${ }^{4}$ Pacific Southwest Research Station, US Forest Service, Fresno, CA, USA \\ ${ }^{5}$ Department of Natural Resources and Environmental Science, University of Nevada, Reno, USA
}

Correspondence to: E. M. Stacy (estacy@ucmerced.edu)

Received: 20 October 2014 - Published in Biogeosciences Discuss.: 4 February 2015

Revised: 13 July 2015 - Accepted: 22 July 2015 - Published: 17 August 2015

\begin{abstract}
Lateral movement of organic matter (OM) due to erosion is now considered an important flux term in terrestrial carbon $(\mathrm{C})$ and nitrogen $(\mathrm{N})$ budgets, yet most published studies on the role of erosion focus on agricultural or grassland ecosystems. To date, little information is available on the rate and nature of OM eroded from forest ecosystems. We present annual sediment composition and yield, for water years 2005-2011, from eight catchments in the southern part of the Sierra Nevada, California. Sediment was compared to soil at three different landform positions from the source slopes to determine if there is selective transport of organic matter or different mineral particle size classes. Sediment export varied from 0.4 to $177 \mathrm{~kg} \mathrm{ha}^{-1}$, while export of $\mathrm{C}$ in sediment was between 0.025 and $4.2 \mathrm{~kg} \mathrm{Cha}^{-1}$ and export of $\mathrm{N}$ in sediment was between 0.001 and $0.04 \mathrm{~kg} \mathrm{~N} \mathrm{ha}^{-1}$. Sediment yield and composition showed high interannual variation. In our study catchments, erosion laterally mobilized OM-rich litter material and topsoil, some of which enters streams owing to the catchment topography where steep slopes border stream channels. Annual lateral sediment export was positively and strongly correlated with stream discharge, while $\mathrm{C}$ and $\mathrm{N}$ concentrations were both negatively correlated with stream discharge; hence, $\mathrm{C}: \mathrm{N}$ ratios were not strongly correlated to sediment yield. Our results suggest that stream discharge, more than sediment source, is a primary factor controlling the magnitude of $\mathrm{C}$ and $\mathrm{N}$ export from upland forest
\end{abstract}

catchments. The OM-rich nature of eroded sediment raises important questions about the fate of the eroded OM. If a large fraction of the soil organic matter (SOM) eroded from forest ecosystems is lost during transport or after deposition, the contribution of forest ecosystems to the erosion-induced $\mathrm{C}$ sink is likely to be small (compared to croplands and grasslands).

\section{Introduction}

The processes of soil erosion and terrestrial sedimentation have been a focus of a growing number of studies because of their potential to induce a net terrestrial sink for atmospheric carbon dioxide $\left(\mathrm{CO}_{2}\right.$; Stallard, 1998; Berhe et al., 2007). Erosion can lead to terrestrial $\mathrm{C}$ sequestration if erosional loss of soil $\mathrm{C}$ from slopes is more than offset by stabilization of eroded $\mathrm{C}$ in depositional landform positions and (at least partial) replacement of eroded $\mathrm{C}$ by production of new photosynthate within the eroding catchment (Stallard, 1998; Harden et al., 1999, 2008; Berhe et al., 2007; Nadeu et al., 2012; Sanderman and Chappell, 2013).

Recent studies have identified major implications of erosion on soil organic matter (SOM) stabilization, changes in composition, and input to the soil system. Identified stabilization mechanisms for this eroded organic matter (OM) de- 
posited in low-lying landform positions include burial, aggregation, and sorption of $\mathrm{OM}$ on the surfaces of reactive soil minerals (Berhe et al., 2012a, 2015; Vandenbygaart et al., 2012), and changes in the biomolecular composition of OM during transport (Rumpel and Kogel-Knabner, 2011; Vandenbygaart et al., 2015). Removal of organic- and nutrientrich topsoil material from eroding positions and its concomitant accumulation in depositional landform positions also has impacts for net primary productivity (NPP) in both locations (Yoo et al., 2005; Berhe et al., 2008; Parfitt et al., 2013). These factors - the balance of organic matter production, stabilization and loss across the landscape - are ecosystemspecific. Several studies have assessed the impact of erosion on C balances in agricultural lands (Van Oost et al., 2007; Quinton et al., 2010; Chappell et al., 2012; Vanderbygaart et al., 2012; Rumpel et al., 2014). Some ecosystems with less human influence have also been studied in this context (Yoo et al., 2006; Berhe et al., 2008; Boix-Fayos et al., 2009; Hancock et al., 2010; Nadeu et al., 2012), but there are currently few published data from minimally disturbed temperate forests.

Erosion processes in forested ecosystems, especially upland or steep catchments, have notable differences from agroecosystems. For instance, average sediment erosion rates are orders of magnitude higher for agricultural lands compared to forested lands (Pimentel and Kounang, 1998). Forest land erosion rates are lower in part due to greater live plant and litter cover of the mineral soil than in agroecosystems, as the vegetation cover reduces the energy of incoming precipitation. In landscapes that have experienced little anthropogenic disturbance, overland erosion transports material from the uppermost soil horizons, which often have a high proportion of undecomposed $\mathrm{OM}$ and high $\mathrm{C}$ concentrations. Such $\mathrm{C}$ enrichment in the transported material relative to the residual soil has been observed in croplands and rangelands, but increased incision into the landscape - through gullies, mass wasting or other processes - also erodes material from deeper layers with lower $\mathrm{C}$ concentrations in these managed ecosystems, resulting in relatively low $\mathrm{C}$ enrichments (Nadeu et al., 2011). The intensive cultural practices used frequently in agricultural, but less often in forestry, such as tilling or vegetation removal, disrupt soil stability and can increase erosion by orders of magnitude (e.g., Pimentel and Kounang, 1998; Van Oost et al., 2006).

Sediment exported from small, minimally disturbed loworder catchments can experience $\mathrm{C}$ oxidation during transport (Berhe, 2012) through the disruption of aggregates (Nadeu et al., 2011; Boix-Fayos et al., 2015), exposure to oxygen and new microbial decomposers, or other means. The oxidative $\mathrm{C}$ loss during erosion is typically assumed to be less than $20 \%$ in agroecosystems partly owing to the relatively low OM concentrations in these soils (Berhe et al., 2007). This same assumption may not be valid in forested ecosystems because upland forest soils typically have much higher concentrations of $\mathrm{OM}$ in surficial soils (as organic horizons or OM-rich mineral topsoil). Furthermore, $\mathrm{C}$ in forested soils or undisturbed grasslands is likely to have a larger unprotected (free, light) fraction compared to agricultural soils, where most of the $\mathrm{C}$ is typically associated with the soil mineral fraction (Berhe et al., 2012a; Wang et al., 2014; Wiaux et al., 2013; Stacy, 2012). Hence, forested sites are likely to have a substantially higher proportion of their eroded OM transported as unprotected, carbon-rich sediments that are free from any physical (aggregation) or chemical (bonding, complexation) association with soil minerals when compared to the better-studied agricultural soils.

Furthermore, determining the role of erosion on forested ecosystems is timely since even forested systems that previously did not experience much anthropogenic modification are expected to experience considerable changes in precipitation amount, timing, and nature with anticipated changes in climate. Anticipated changes in climate are expected to have important implications for sediment and OM erosion from forest ecosystems. In the Sierra Nevada, large tracts of relatively undisturbed forest still exist. Even though some land has experienced intensive management for timber production (especially in historical periods), most is only minimally influenced by human activities, including fire management, roads, and the water reservoir system. In these ecosystems, increasing temperatures associated with climate change are expected to alter the erosional process due to the anticipated shift in the nature of precipitation. A shift in the type of precipitation from snow to rain, and a higher number of rain-onsnow events, compared to even the last few decades (Bales et al., 2006; IPCC, 2007; Klos et al., 2014), are expected to provide greater force to detach, scour, and transport material from the soil overall (Boix-Fayos et al., 2009; Nadeu et al., 2011), with subsequent implications for amount of $\mathrm{C}$ transported. Higher erosive forces will also provide more energy to disrupt aggregates, exposing OM previously protected from decomposition to loss (Nadeu et al., 2011). The dearth of data on the effect of climate change on soil C erosion is complicated by the inherent variability of erosion events, such as episodic, large storm events or an extreme weather season, that make it challenging to create conceptual or numerical models that can easily scale up across time and space (Kirkby, 2010).

Here, we focus on determining the nature and magnitude of the sediment and associated OM exported out of forested upland catchments at mid-range scales (spatially and temporally) to further our understanding of how climate affects soil erosion processes in such ecosystems. We quantified the mass and composition of sediments exported from eight loworder catchments to determine the effect of soil erosion on $\mathrm{C}$ and $\mathrm{N}$ dynamics in these upland forest ecosystems. Our study catchments are located in the southern Sierra Nevada, at two contrasting elevation zones with differences in the proportion of precipitation falling as rain or snow. This work builds on previous publications on the sediment transport and composition from the same site (Eagan et al., 2007; Hunsaker and 
Neary, 2012), covering sediment transport for all water years (2005-2011) after the construction of all sediment basins and prior to planned forest management treatments (fire and thinning); implementation of those treatments began in 2012 . In addition, we expand on the characterization of sediment composition with additional measurements and a comparison to soil samples from potential source locations. This work is part of a larger investigation at this site on changes in OM stabilization mechanisms due to erosion. Specifically, we addressed two critical questions:

1. in forested catchments with minimal disturbance, how are rates of sediment yield related to interannual and elevational differences in precipitation?

2. Is the chemical composition of eroded sediments better correlated to catchment characteristics (e.g., soil properties and slope geometry) or climate (e.g., precipitation form, water yield timing)?

We hypothesized that variation in sediment yield is directly related to stream discharge (as a proxy for precipitation), based on results from previous years, and that the precipitation form would impact sediment yield due to the higher energy of rain events compared to snow, and the greater potential for rain-on-snow events at lower elevations in the Sierras. We also hypothesized that sediment chemical composition (in contrast to total yield) is better correlated with watershed characteristics than with precipitation amount or water yield timing.

\section{Site description and methods}

\subsection{Site description}

This study was conducted within the US Forest Service Kings River Experimental Watersheds (KREW), located in the Sierra National Forest $\left(37.012^{\circ} \mathrm{N}, 119.117^{\circ} \mathrm{W}\right.$; Fig. 1). We used eight low-order catchments (48-227 ha in size), grouped within two elevation zones as the Providence and Bull catchments (Fig. 2). The Providence catchments (1485$2115 \mathrm{~m}$ elevation) receive a mix of rain and snow (about $35-60 \%$ snow). Approximately $15 \mathrm{~km}$ to the southeast, the higher-elevation Bull catchments (2050-2490 m) receive the majority (75-90\%) of precipitation as snow. Both elevation groups experience a Mediterranean-type climate with the majority of precipitation (rain or snow) falling in the winter. The lower-elevation Providence catchments are also being investigated as part of the Southern Sierra Critical Zone Observatory (CZO, www.criticalzone.org/sierra) project. Mean ( \pm standard deviation) annual air temperature for water years 2004-2007 was $11.3( \pm 0.8)$ and $7.8\left( \pm 1.4^{\circ} \mathrm{C}\right)$ at the lowand high-elevation sites, respectively (Johnson et al., 2011). Annual precipitation during the years of this study (water years 2005-2011) was similar across elevations but varied more than twofold among years $(750-2200 \mathrm{~mm}$, Fig. 2,

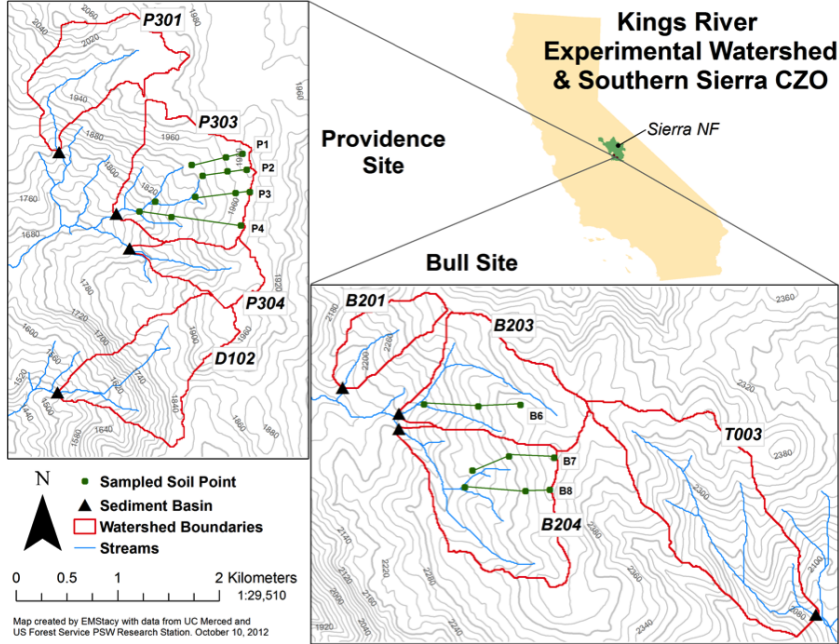

Figure 1. Map of the Kings River Experimental Watershed and Southern Sierra Critical Zone Observatory showing soil sampling points (green circles, at depositional, backslope, and crest hillslope positions from left to right along transects) and sediment sampling basins (black triangles).

see Hunsaker and Neary (2012) and Climate and Hydrology Database Projects [CLIMDB/HYDRODB], www.fsl. orst.edu/climhy).

Seven of the catchments have experienced common forest management practices such as timber harvest, tree planting, grazing, and road construction and maintenance. However, no activities other than occasional road grading and grazing have occurred in the past 15 years since KREW was established. One catchment (T003) is undisturbed and has never had timber harvest or road construction. No fire has been recorded in these catchments for 110 years.

Both the lower- and higher-elevation sites are characterized as Sierra mixed-conifer forests, with a more open canopy at Bull than Providence (Fig. 3). Dominant tree species at Providence Creek site include sugar pine $(P i$ $n u s$ lambertiana), ponderosa pine (P. ponderosa), incense cedar (Calocedrus decurrens), white fir (Abies concolor), and black oak (Quercus kelloggii). At the higher-elevation Bull Creek site, red fir (A. magnifica), sugar pine, and Jeffrey pine (P. jeffreyi) are more dominant. For more information on land cover see Bales et al. (2011) and Johnson et al. (2011).

Soil in the study area is derived from granite and granodiorite bedrock. Dominant soil series include Shaver, Cagwin, and Gerle-Cagwin. The Shaver series is most prominent (48-66\% coverage) in the Providence catchments, while the higher-elevation Bull catchments are dominated by the Cagwin series (67-98\% coverage; Johnson et al., 2011). The Shaver series is in the US Department of Agriculture Soil Taxonomic family of coarse-loamy, mixed mesic Pachic Xerumbrepts. The Cagwin series is in the loamy coarse sand, mixed, frigid Dystric Xeropsamments family. The Gerle se- 

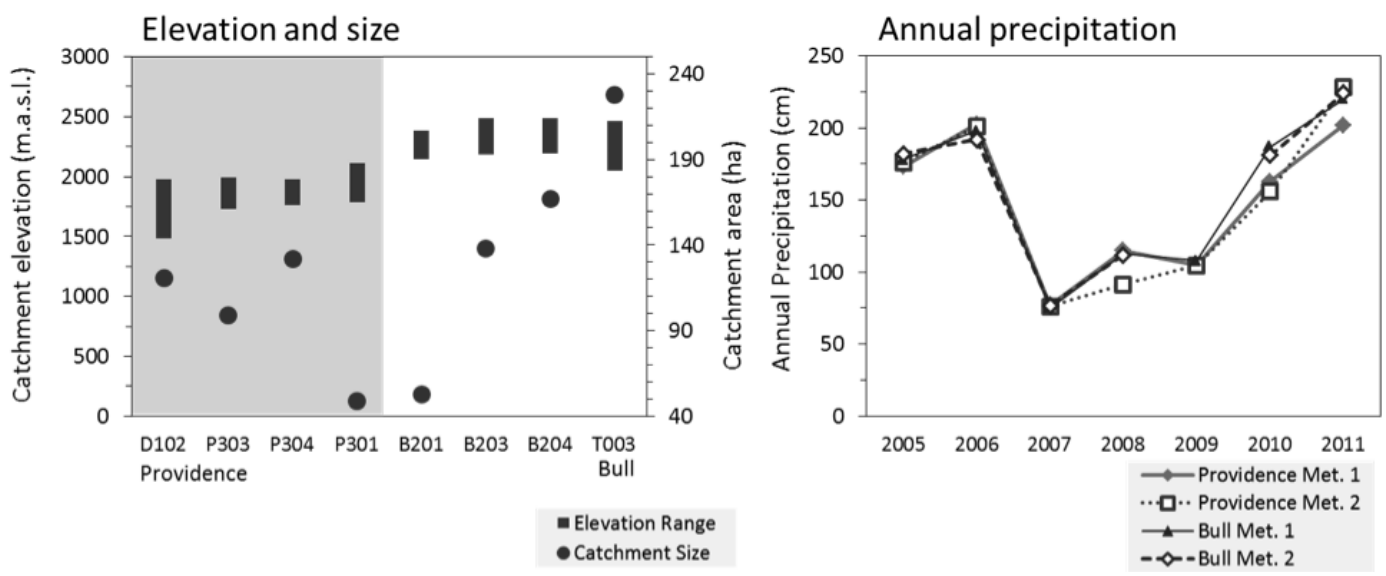

Figure 2. Elevation range and size of the catchments (left) and annual precipitation from four meteorological stations (right) during the years of study. Roughly half of the precipitation at the lower-elevation Providence catchments falls as rain, while the Bull catchments (high elevation) receive $>75 \%$ of precipitation as snow.
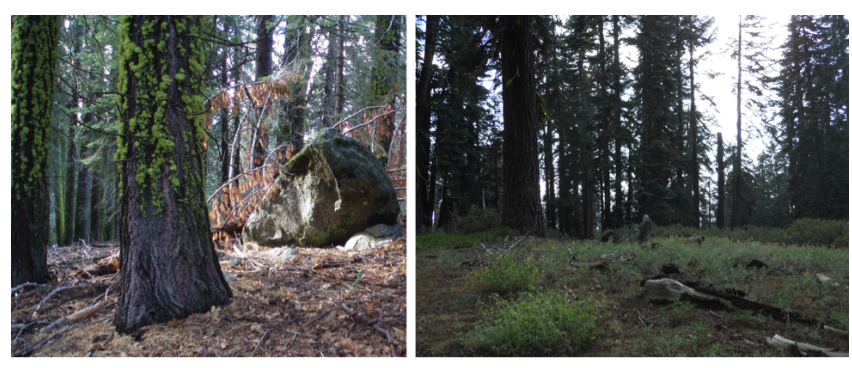

Figure 3. Forests at Providence (left) and Bull (right) catchments. At both sites, vegetation cover is variable, with occasional clearings, meadows, and exposed bedrock.

ries is in the coarse-loamy, mixed, frigid Typic Xerumbrepts family. Johnson et al. (2011) give detailed information on chemical and physical variation of soil in the study catchments. The dominant aspect of these catchments is southwest (Bales et al., 2011).

\subsection{Methods}

Stream discharge was quantified using a pair of flumes on each stream (Hunsaker et al., 2007). Annual stream discharge presented here was integrated from average daily flow rates based on continuous $15 \mathrm{~min}$ interval sampling. We characterized newly collected sediment samples from the catchments for water years 2009-2011 (Table 1) and sediment samples from water years 2005, 2007, and 2008 (Eagan et al., 2007; Hunsaker and Neary, 2012) that were collected and archived by the US Forest Service Pacific Southwest Research Station in Fresno, CA (stored air-dried, at room temperature in the dark). There were no archived sediments preserved from water year 2006.

Sediment from each catchment was captured in basins that allow sediment particles to settle as stream water slows pass- ing through the basin (Eagan et al., 2007). Constructed to fit the topography, basin dimensions vary in size but are about $2-3 \mathrm{~m}$ wide by $8-15 \mathrm{~m}$ long. Annual sediment loads were quantified at the end of the water year (WY; 1 October of the previous year through 30 September) in August and September, when water flows were lowest. Streams were diverted underneath the basin lining for collection. Material in the sediment basins was emptied using buckets and shovels and weighed in the field using a hanging spring scale (capacity of $50 \pm 0.5 \mathrm{~kg})$. A representative sample $(\sim 20 \mathrm{~kg})$ was returned to the US Forest Service Pacific Southwest Research Station Fresno office. Subsamples ( $2 \mathrm{~kg}$ ) for WY 2009-2011 were transported in a cooler to UC Merced and stored at $4{ }^{\circ} \mathrm{C}$ until further processing.

Sediment samples were compared to soil samples considered as potential sources, collected from 18 sampling points along representative transects for each elevation group of catchments (see Fig. 1). Sites were selected to be as comparable as possible; however, transect P2 had a nonrepresentative, highly saturated meadow as the depositional location. Transect P2 was not evaluated in further analyses because other depositional locations were in the forest. Each transect was laid out along a hillslope toposequence and sampled at crest, backslope, and foot-/toe-slope (hereafter characterized as "depositional") landform positions. Crest samples were taken at the top of the ridgeline, where the slope was $<5^{\circ}$. Backslope samples were taken where the slope change was constant (slopes between 5 and $25^{\circ}$ ). Depositional samples were taken in areas where slopes were converging and curvature was minimal (i.e., below the footslope and as close to flat as possible). These depositional areas cover a limited surface, sometimes only a few meters wide where slopes converge; the catchments are steep and have minimal flat surfaces near the creeks and drainages. To estimate slope at each sampling point, Spatial Analyst tools from 
Table 1. Annual sediment yield per hectare for water years 2005-2011, including mineral material, and coarse and fine organic matter (coarse, $>2 \mathrm{~mm}$, organics are comprised of material pinecones and conifer needles, and accounts for $\sim 4-20 \%$ of fraction; remaining fine organics $(<2 \mathrm{~mm})$ account for $4-30 \%$ of total). These values do not include large woody debris, longer than $30 \mathrm{~cm}$ and with a diameter greater than $2 \mathrm{~cm}$. NA = not available. Sediment was not collected from some basins in 2005, 2006, and 2011 due to basin failures.

\begin{tabular}{lrrrrrrrr}
\hline & & \multicolumn{7}{c}{ Sediment yield $\left(\mathrm{kg} \mathrm{ha}^{-1}\right)$} \\
\cline { 3 - 9 } Catchment & Size (ha) & 2005 & 2006 & 2007 & 2008 & 2009 & 2010 & 2011 \\
\hline D102 & 120.8 & 47.9 & 61.3 & 1.0 & 13.7 & 0.9 & 14.3 & NA \\
P301 & 99.2 & 32.8 & 24.5 & 0.4 & 0.7 & 0.8 & 4.5 & 27.1 \\
P303 & 132.3 & NA & NA & 0.5 & 1.3 & 0.6 & 2.3 & 40.0 \\
P304 & 48.7 & 177.3 & 169.9 & 7.1 & 42.7 & 5.4 & 36.8 & 165.0 \\
B201 & 53.0 & 64.6 & 35.4 & 2.5 & 3.9 & 6.5 & 12.4 & 20.6 \\
B203 & 138.4 & 59.9 & 32.9 & 1.4 & 1.3 & 2.8 & 18.3 & 9.0 \\
B204 & 166.9 & 37.7 & 14.4 & 0.5 & 1.7 & 2.7 & 16.6 & 10.7 \\
T003 & 222.7 & 136.2 & 59.6 & 1.9 & 4.3 & 6.9 & 19.3 & 14.8 \\
\hline
\end{tabular}

the ArcGIS software ArcMap 10.0 (ESRI, Redlands, CA, USA) were used to calculate slope from a $10 \mathrm{~m}$ digital elevation model (DEM). Soil samples from each hillslope position were collected in August and September, 2011, using a hand auger with a $5 \mathrm{~cm}$ diameter bucket. Depths were separated into four layers: organic horizon, $0-10,10-20$ and $20-40 \mathrm{~cm}$. Soil samples were kept in a cooler on ice packs until returned to the laboratory, where they were transferred to a refrigerator and kept at $4{ }^{\circ} \mathrm{C}$ until processing within 3 months. Soil sampling locations were selected to minimize variation in aspect and slope (factors that might influence overland transport and the energy of incoming precipitation). Soil across the catchments was previously characterized (Johnson et al., 2011, 2012), providing a larger data set against which to compare the results of this study.

\subsection{Physical characterization of soil and sediment}

Soil and sediment (air-dried, $<2 \mathrm{~mm}$ sieved samples) $\mathrm{pH}$ was measured in $1: 2(w: w)$ soil-to-water suspension using a combination electrode (Fisher Scientific Accumet Basic AB15 meter, Waltham, Massachusetts). Soils $(0-20 \mathrm{~cm})$ from two transects (selected for comparability based on distance to stream, aspect, and vegetation) were selected for particle size distribution and specific surface area at the Center for Environmental Physics and Mineralogy at the University of Arizona. Before analyses, organic matter was removed from the soil and sediment samples by mixing approximately $20 \mathrm{~g}$ of sample with $100 \mathrm{~mL}$ of sodium hypochlorite $(6 \%$ $\mathrm{NaOCl}$, adjusted to $\mathrm{pH} 9.5$ with $1 \mathrm{M} \mathrm{HCl}$ ) for $30 \mathrm{~min}$ at $60^{\circ} \mathrm{C}$. Subsequently, solutions were centrifuged at $1500 \mathrm{~g}$ for $15 \mathrm{~min}$; then supernatant and floating organic particles were aspirated. This process was repeated twice. After OM removal, $100 \mathrm{~mL}$ of deionized water was added and the centrifuged; the supernatant was aspirated and discarded, and samples were dried at $40^{\circ} \mathrm{C}$. Particle size distribution was determined with laser diffraction and specific surface area with
Brunauer-Emmett-Teller adsorption isotherms (Brunauer et al., 1938).

\subsection{Characterization of $\mathrm{C}$ and $\mathrm{N}$ in sediment and soil}

Total $\mathrm{C}$ and $\mathrm{N}$ were measured at the $<2 \mathrm{~mm}$ fraction following grinding (8000M Spex Mill, SPEX Sample Prep, Metuchen, NJ, USA) with a Costech ECS 4010 CHNSO Analyzer (Valencia, CA, USA). All values have been moisturecorrected and reported here on an oven-dried $\left(105^{\circ} \mathrm{C}\right)$ weight basis.

\subsection{Data analysis}

Data are presented as mean \pm standard error $(n=3)$, except where noted. Explanatory factors for $\mathrm{C}$ and $\mathrm{N}$ concentrations and the $\mathrm{C}: \mathrm{N}$ ratio of sediment and soil were evaluated with a multivariate model to account for sampling year, catchment, sampling depth, and hillslope position. The strength of different model formats and interactions terms was evaluated using a stepwise regression run simultaneously in both directions, with the best model chosen according to the Akaike Information Criterion (Burnham and Anderson, 2002). The Tukey-Kramer HSD test ANOVA was used to test for significant differences between means of sediment mass, and $\mathrm{C}$ or $\mathrm{N}$ concentrations between sediment basins and collection years, and between hillslope position and transects for soils. For all statistical tests, an a priori $\alpha$ level of 0.05 was used to determine statistical significance. Statistical analyses were conducted using R 2.14.2 (http://www.r-project.org).

\section{Results}

\subsection{Sediment yield and organic matter export}

Area-normalized sediment yield (hereafter referred to as sediment yield) in the eight catchments varied over several orders of magnitude. There were large differences among years 
and catchments (Fig. 4, Table 1). Mean annual sediment yield across all catchments and years was $26.0 \pm 6.1 \mathrm{~kg} \mathrm{ha}^{-1}$, but ranged from 0.4 to $177 \mathrm{~kg} \mathrm{ha}^{-1}$. The lowest mean sediment yield $\left(8.9 \pm 4.0 \mathrm{~kg} \mathrm{ha}^{-1}\right)$ was recorded for the P303 catchment. The highest interannual variability in sediment yield was observed in catchments D102, B204, and T003. Sediment yield was positively correlated with total annual water yield (Fig. 4). Across all catchments and years, there was a good correlation between water yield and sediment yield:

$\log _{10}[S]=1.87 \cdot \log _{10}[W]-0.307$

$\left(R^{2}=0.62, p<0.0001, n=52\right)$,

where $S=$ annual sediment yield $\left(\mathrm{kg} \mathrm{ha}^{-1} \mathrm{yr}^{-1}\right)$ and $W=$ annual water yield $\left(1000 \mathrm{~m}^{3} \mathrm{ha}^{-1} \mathrm{yr}^{-1}\right)$.

The P304 catchment had very high export rates relative to the other catchments; excluding this catchment improved the $R^{2}$ value to $0.72(p<0.001, n=45)$.

In contrast to the sediment yield, $\mathrm{C}$ (Fig. 4) and $\mathrm{N}$ (not shown) concentrations in the sediment were both negatively correlated with annual water yield $\left(R^{2}=0.31, p<0.001\right.$, $n=45$ for $\mathrm{C}$; and $R^{2}=0.36, p<0.001, n=45$ for $\left.\mathrm{N}\right)$. As a result, the sediment $\mathrm{C}$-to- $\mathrm{N}(\mathrm{C}: \mathrm{N})$ mass ratio was only weakly correlated to water yield $\left(R^{2}=0.10, p=0.019\right.$, $n=45$; Fig. 4). Much of the organic matter collected in the sediment basins is recognizable (by the naked eye or under $25 \times$ magnification) as undecomposed organic matter. Further methods and results of the mass of transported sediment are available in Hunsaker and Neary (2012). The total export of particulate $\mathrm{C}$ in the $<2 \mathrm{~mm}$ fraction ranged from 0.17 to $46.9 \mathrm{~kg} \mathrm{Cha}^{-1}$ while particulate $\mathrm{N}$ export was 0.008 $1.7 \mathrm{~kg} \mathrm{Nha}^{-1}$.

\section{2 $\mathrm{C}$ and $\mathrm{N}$ concentrations in sediment and soil}

Sediment yield among both catchments and years was more variable (higher coefficients of variation) than the sediment $\mathrm{C}$ and $\mathrm{N}$ concentrations (Table 4). While sediment composition was less variable than sediment yield overall, $\mathrm{C}$ and $\mathrm{N}$ concentrations still showed statistically significant interannual and interbasin variation (Fig. 5). Catchment size, catchment elevation group, and mean elevations were eliminated as significantly contributing variables in a stepwise regression model run simultaneously in both directions. In the sediment samples, C concentrations ranged from 15.5 to $190 \mathrm{~g} \mathrm{~kg}^{-1}$ and $\mathrm{N}$ from 0.50 to $7.10 \mathrm{~g} \mathrm{~kg}^{-1}$ (Table 2). In a multivariate general linear model, both year $(p<0.001)$ and source catchment $(p<0.01)$ significantly influenced $\mathrm{C}$ and $\mathrm{N}$ concentrations $(n=45)$. This treats each sediment sample as independent but interactions between catchment and year could not be evaluated because there was insufficient replication. Sediment yield was inversely correlated with $\mathrm{C}$ and $\mathrm{N}$ concentrations $\left(R^{2}=0.26\right.$ and 0.19 , respectively; $\left.p<0.01, n=46\right)$. For seven catchments, the $\mathrm{C}: \mathrm{N}$ ratio ranged from 20.4 to 36.8 , with a mean of 27.1 (Fig. 5f). The only significant difference among catchments was found in the upper elevation
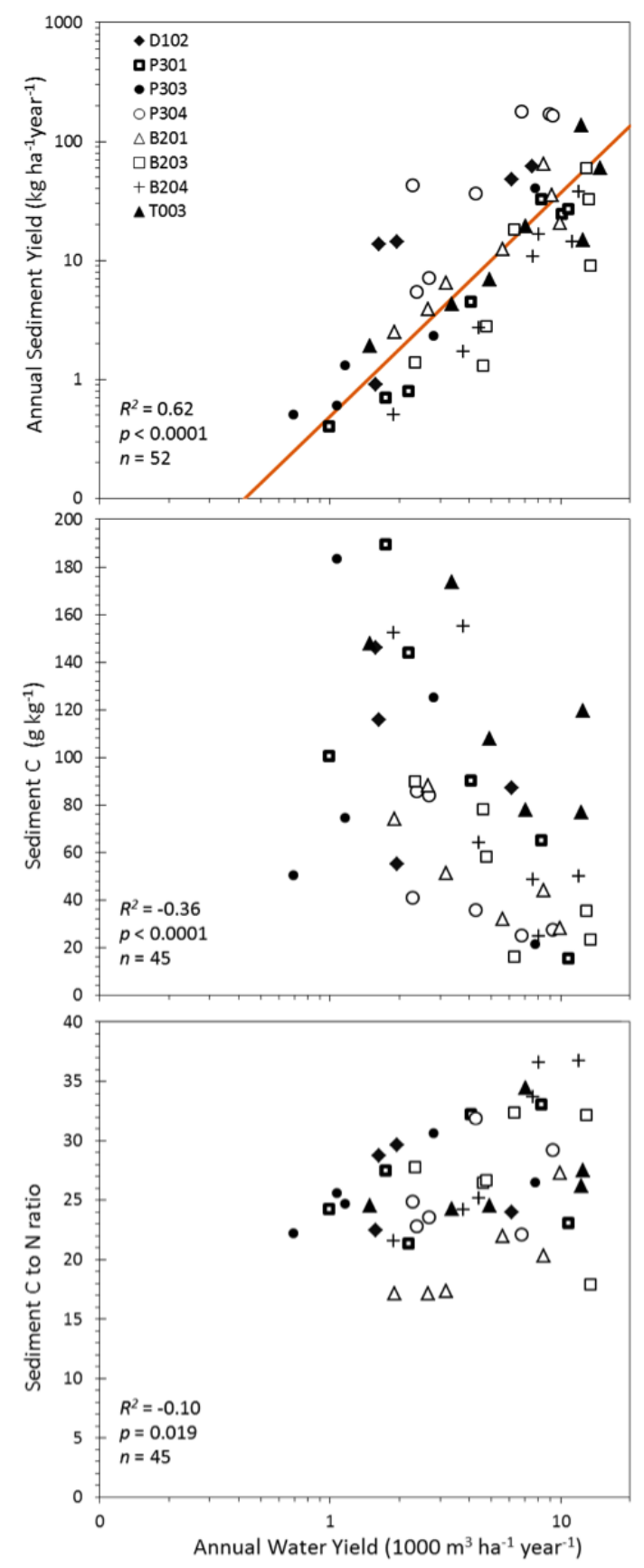

Figure 4. Top: annual sediment yield is directly correlated with annual water yield. Middle: annual sediment carbon (C) and nitrogen (N; not shown) concentrations have an inverse relationship to water yield. Bottom: the C-to-N mass ratio is weakly correlated with water yield. Data presented for WY 2005, and 2007-2011 (sediment basins constructed over the period 2002-2004, samples were not preserved for testing from WY 2006).

catchment, B201, which had comparatively higher N concentrations; B201 sediment constitutes the outliers in Fig. 5e.

Mineral soils had similar $\mathrm{C}$ and $\mathrm{N}$ concentrations and $\mathrm{C}: \mathrm{N}$ ratios at both sampling sites (Table 3). The low-elevation 
Table 2. Physical and chemical characterization of the sediment material $(<2 \mathrm{~mm})$, including $\mathrm{pH}_{\mathrm{water}}(1: 2 w / v)$, carbon $(\mathrm{C})$ and nitrogen (N) concentrations, and particle size distribution (clay $<2 \mu \mathrm{m}$, silt $2-50 \mu \mathrm{m}$, and sand 50-2000 $\mu \mathrm{m}$ ). Some samples were not measured due to lack of material (indicated by no data or nd). SSA is specific surface analysis and nd means no data.

\begin{tabular}{|c|c|c|c|c|c|c|c|c|}
\hline $\begin{array}{l}\text { Catchment and } \\
\text { water year }\end{array}$ & $\mathrm{pH}_{\mathrm{w}}^{\mathrm{a}}$ & $\begin{array}{r}\mathrm{C} \\
\left(\mathrm{g} \mathrm{kg}^{-1}\right)^{\mathrm{b}}\end{array}$ & $\begin{array}{r}\mathrm{N} \\
\left(\mathrm{g} \mathrm{kg}^{-1}\right)^{\mathrm{c}}\end{array}$ & $\begin{array}{l}\mathrm{C}: \mathrm{N} \\
\text { ratio }\end{array}$ & $\begin{array}{r}\text { Clay } \\
\left(\mathrm{g} \mathrm{kg}^{-1}\right)^{\mathrm{d}}\end{array}$ & $\begin{array}{r}\text { Silt } \\
\left(\mathrm{g} \mathrm{kg}^{-1}\right)^{\mathrm{d}}\end{array}$ & $\begin{array}{r}\text { Sand } \\
\left(\mathrm{g} \mathrm{kg}^{-1}\right)^{\mathrm{d}}\end{array}$ & $\begin{array}{r}\text { SSA } \\
\left(\mathrm{m}^{2} \mathrm{~g}^{-1}\right)^{\mathrm{d}}\end{array}$ \\
\hline \multicolumn{9}{|l|}{ D102 } \\
\hline WY 2009 & $5.8^{\mathrm{e}}$ & 146.1 & 6.5 & 22.5 & $\mathrm{nd}^{\mathrm{e}}$ & nd & nd & nd \\
\hline WY 2010 & 5.9 & 55.1 & 1.9 & 29.7 & 69 & 247 & 685 & 1.53 \\
\hline WY 2011 & nd & nd & nd & nd & nd & nd & nd & nd \\
\hline \multicolumn{9}{|l|}{ P301 } \\
\hline WY 2009 & 5.5 & 144.0 & 6.7 & 21.4 & 74 & 385 & 541 & 2.87 \\
\hline WY 2010 & 5.5 & 90.2 & 2.8 & 32.4 & 79 & 298 & 623 & 2.41 \\
\hline WY 2011 & 5.8 & 28.4 & 1.0 & 27.4 & 51 & 215 & 734 & 2.42 \\
\hline \multicolumn{9}{|l|}{ P303 } \\
\hline WY 2009 & 5.0 & 183.3 & 7.1 & 25.7 & 60 & 343 & 597 & 1.80 \\
\hline WY 2010 & 5.5 & 125.3 & 4.1 & 30.7 & 83 & 331 & 587 & 2.27 \\
\hline WY 2011 & 5.8 & 21.3 & 0.8 & 26.6 & 53 & 209 & 738 & 3.49 \\
\hline \multicolumn{9}{|l|}{ P304 } \\
\hline WY 2009 & 5.1 & 85.9 & 3.8 & 22.9 & 135 & 383 & 482 & 7.60 \\
\hline WY 2010 & 5.7 & 35.8 & 1.1 & 32.0 & 110 & 297 & 594 & 5.11 \\
\hline WY 2011 & 5.9 & 15.5 & 0.7 & 23.2 & 72 & 246 & 682 & 3.53 \\
\hline \multicolumn{9}{|l|}{ B201 } \\
\hline WY 2009 & 4.8 & 51.4 & 2.9 & 17.4 & 150 & 315 & 536 & 6.42 \\
\hline WY 2010 & 5.4 & 31.9 & 1.4 & 22.0 & 123 & 289 & 588 & 5.07 \\
\hline WY 2011 & 5.4 & 23.5 & 1.3 & 18.0 & 112 & 287 & 602 & 3.65 \\
\hline \multicolumn{9}{|l|}{ B203 } \\
\hline WY 2009 & 4.7 & 58.4 & 2.2 & 26.8 & 58 & 245 & 698 & 1.05 \\
\hline WY 2010 & 5.5 & 16.4 & 0.5 & 32.5 & 69 & 198 & 734 & 1.77 \\
\hline WY 2011 & 5.4 & 27.5 & 0.9 & 29.3 & 56 & 212 & 732 & 1.13 \\
\hline \multicolumn{9}{|l|}{ B204 } \\
\hline WY 2009 & 5.0 & 64.3 & 2.5 & 25.3 & 58 & 233 & 709 & 1.99 \\
\hline WY 2010 & 5.4 & 24.7 & 0.70 & 36.7 & 70 & 246 & 685 & 2.18 \\
\hline WY 2011 & 5.3 & 48.6 & 1.4 & 33.8 & 69 & 246 & 685 & 2.28 \\
\hline \multicolumn{9}{|l|}{ T003 } \\
\hline WY 2009 & 5.4 & 107.8 & 4.4 & 24.6 & 53 & 322 & 625 & 1.51 \\
\hline WY 2010 & 5.6 & 78.1 & 2.3 & 34.6 & 68 & 304 & 629 & 1.99 \\
\hline WY 2011 & 5.5 & 119.5 & 4.3 & 27.6 & 76 & 339 & 585 & 2.46 \\
\hline
\end{tabular}

${ }^{\text {a }}$ Standard error $\leq 0.06$ for replicates; ${ }^{\mathrm{b}}$ standard error $\leq 0.03$ for analytical $(n \geq 3)$ replicates; ${ }^{\mathrm{c}}$ standard error $\leq 0.8$ for analytical $(n \geq 3)$ replicates; $\mathrm{d}_{n=3}$ analytical replicates. ${ }^{\mathrm{e}}$ Due to the limited mass of archived material, the $\mathrm{pH}$ value for D102 from WY2009 is given from an analysis as $\mathrm{pH}_{\text {water }}$ with $1: 2.5$ soil weight to water volume.

Providence catchment had a wider range in $\mathrm{C}$ concentrations $\left(9.0\right.$ to $\left.98 \mathrm{~g} \mathrm{~kg}^{-1}\right)$ in the surface soil $(0-10 \mathrm{~cm})$ than the Bull catchment soils (18.0-63.0 $\mathrm{g} \mathrm{kg}^{-1}$, except for one depositional point that had a $\mathrm{C}$ concentration of $167 \mathrm{~g} \mathrm{~kg}^{-1}$ ). The $\mathrm{N}$ concentrations in surface soil ranged from 0.5 to $3.5 \mathrm{~g} \mathrm{~kg}^{-1}$ in Providence, and 1.0 to $5.1 \mathrm{~g} \mathrm{~kg}^{-1}$ in Bull. Differences between the elevation groups were not statistically significant
(ANOVA; $p>0.40$ ) for either $\mathrm{C}$ or $\mathrm{N}$ soil concentrations. The greatest differences were between the organic and the mineral soil horizons. The $\mathrm{C}: \mathrm{N}$ ratio of the organic horizon was statistically higher than the mineral soils (means $51 \pm 3.9$ and $25 \pm 0.9 \%$, respectively, $p<0.0001$ ). The organic horizon chemical composition had consistent $\mathrm{C}$ and $\mathrm{N}$ concentrations, $\mathrm{C}: \mathrm{N}$ ratio, landform positions, transects, 


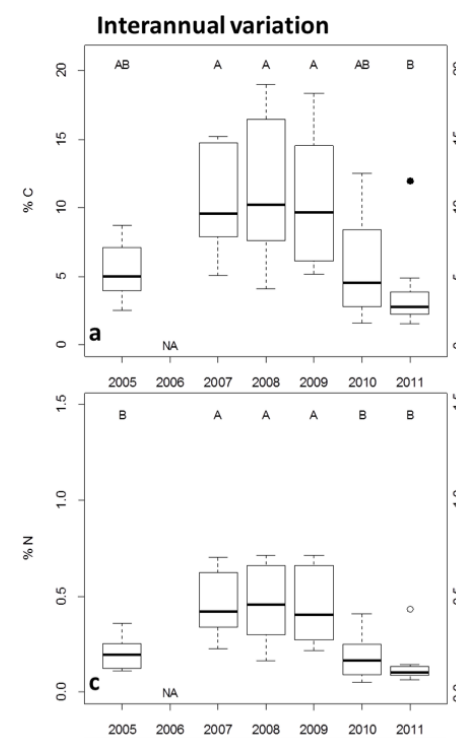

Interbasin variation
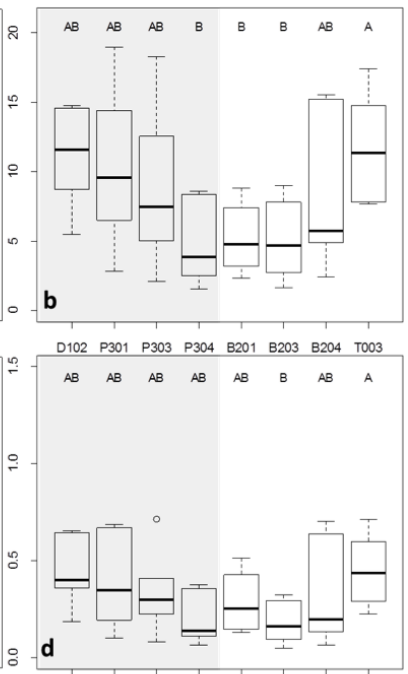

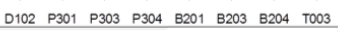
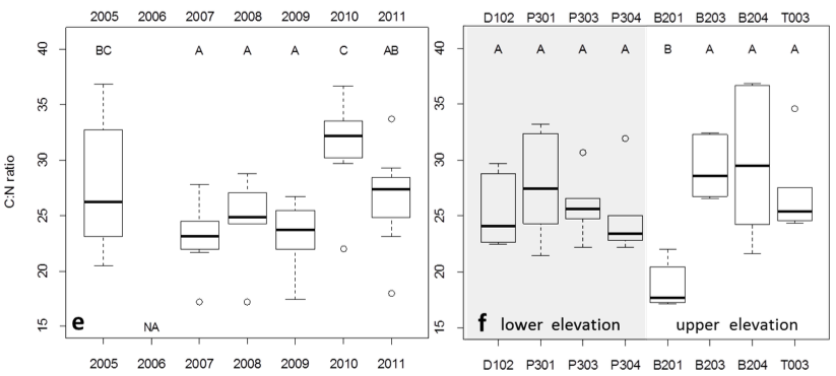

Figure 5. Carbon $(\mathrm{C})$ and nitrogen $(\mathrm{N})$ concentrations and $\mathrm{C}: \mathrm{N}$ mass ratios of $<2 \mathrm{~mm}$ material collected in sediment basins within the Providence (low-elevation) and Bull (high elevation) catchments between water years 2005 and 2011. Left panels (a, c and e) show interannual variation in these variables, while right panels $(\mathbf{b}, \mathbf{d}$, and f) show interbasin variation (Providence catchments highlighted by shading). The bold line in the boxplot marks the median, and boxes mark the interquartile range, with the full range indicated by the fences save for outliers more than 1.5 times the box width from the box edge, marked by circles. Different means as determined by ANOVA using a Tukey HSD test $(\alpha=0.05)$ are designated with letters. Archive samples for 2006 were not available for testing $(\mathrm{NA}=$ not available $)$.

and catchments (data not shown). Depositional hillslope positions had significantly higher mineral soil $\mathrm{C}$ and $\mathrm{N}$ concentrations than both the crest and backslope positions, which were similar (Table 3). Mineral soils in depositional locations had the most variation in composition among the soil samples analyzed. Sediment $C$ concentrations in water years 2005, 2010, and 2011 were statistically similar to the soil range $(p>0.95)$, but in the other years, sediment $\mathrm{C}$ and $\mathrm{N}$ concentrations were much higher than soils $(p<0.05)$.
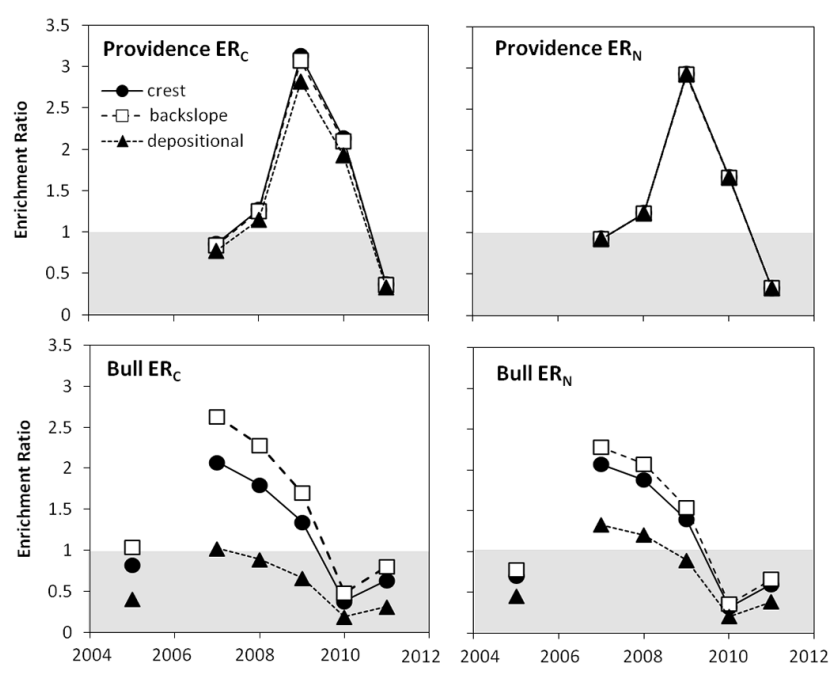

Figure 6. Enrichment ratios for carbon $\left(E R_{C}\right)$ and nitrogen $\left(E R_{N}\right)$ in material $(<2 \mathrm{~mm})$ collected from sediment basins at the outlet of each catchment over the water years 2005-2011. Different symbols represent enrichment ratios calculated using average surface mineral soil $(0-10 \mathrm{~cm})$ values for the three hillslope positions studied in Providence (low elevation) and Bull (high-elevation) catchments. Sediment basins were installed over the years 2002-2004 and archived samples were not preserved for many sediment basins in 2006 or before 2005 .

\subsection{Physical and chemical characteristics of sediment and soil}

Sediments exported from all of the study catchments had higher sand concentrations and lower clay concentrations compared to surface mineral soils in the source hillslope $(p<0.001$; Tables 2 and 3). Silt concentration of WY 2009 sediment was higher $(p=0.02)$ than WY 2011 sediment but still lower $(p=0.03)$ than soil values. Soil texture classification was sandy-loam to loam and the particle size distribution was consistent across landform positions and mineral soil depths (Table 3). Consistent with the coarser particles, sediment had lower specific surface area than the mineral soil. Of the three years evaluated, sediment from 2009 had the highest specific surface area $\left(3.3 \pm 1.0 \mathrm{~m}^{2} \mathrm{~g}^{-1}\right.$; Table 2). Surface mineral soil in the higher-elevation B8 transect had a specific surface area of $8.5 \pm 1.7 \mathrm{~m}^{2} \mathrm{~g}^{-1}$, while the lowerelevation $\mathrm{P} 4$ transect had $10.3 \pm 1.6 \mathrm{~m}^{2} \mathrm{~g}^{-1}$ (Table 3).

Soil $\mathrm{pH}$ declined with elevation, with higher $\mathrm{pH}$ values in the low-elevation Providence catchments than the Bull catchments ( $p=0.002$; Table 3 ), but there were no differences among mineral soil depths. Sediment from the higher catchments was also more acidic than the sediment from the lower catchments $(p=0.03)$, but the means were more similar than the respective source mineral soils. Sediment (WY 20092011) had significantly lower $\mathrm{pH}$ than the soils $(p=0.01)$. 
Table 3. Mineral soil physical and chemical characterizations (air-dried $<2 \mathrm{~mm}$ ) for a subset of the soil transects (the two sent out for physical analysis), including $\mathrm{pH}_{\text {water }}(1: 2 \mathrm{w} / \mathrm{v})$, carbon $(\mathrm{C})$ and nitrogen $(\mathrm{N})$ concentrations, $\mathrm{C}: \mathrm{N}$ mass ratio, particle size distribution, and specific surface analysis (SSA).

\begin{tabular}{|c|c|c|c|c|c|c|c|c|c|}
\hline $\begin{array}{l}\text { Catchment and } \\
\text { hillslope positions }\end{array}$ & $\begin{array}{r}\text { Depth } \\
(\mathrm{cm})\end{array}$ & $\mathrm{pH}_{\mathrm{w}}^{\mathrm{a}}$ & $\begin{array}{r}\mathrm{C} \\
\left(\mathrm{g} \mathrm{kg}^{-1}\right)^{\mathrm{b}}\end{array}$ & $\begin{array}{r}\mathrm{N} \\
\left(\mathrm{g} \mathrm{kg}^{-1}\right)^{\mathrm{c}}\end{array}$ & $\begin{array}{l}\mathrm{C}: \mathrm{N} \\
\text { ratio }\end{array}$ & $\begin{array}{r}\text { Clay } \\
\left(\mathrm{g} \mathrm{kg}^{-1}\right)\end{array}$ & $\begin{array}{r}\text { Silt } \\
\left(\mathrm{g} \mathrm{kg}^{-1}\right)\end{array}$ & $\begin{array}{r}\text { Sand } \\
\left(\mathrm{g} \mathrm{kg}^{-1}\right)\end{array}$ & $\begin{array}{r}\text { SSA } \\
\left(\mathrm{m}^{2} \mathrm{~g}^{-1}\right)\end{array}$ \\
\hline \multicolumn{10}{|l|}{ P303 transect P4 } \\
\hline \multirow[t]{3}{*}{ Crest } & $0-10$ & 6.2 & 54.0 & 2.6 & 20.9 & 117 & 365 & 518 & 6.96 \\
\hline & $10-20$ & 5.4 & 35.6 & 1.6 & 21.6 & 106 & 371 & 523 & 9.27 \\
\hline & $20-39$ & & 24.5 & 1.1 & 25.8 & nd & nd & nd & nd \\
\hline \multirow[t]{3}{*}{ Backslope } & $0-10$ & 6.3 & 85.4 & 3.4 & 25.1 & 122 & 375 & 503 & 11.99 \\
\hline & $10-20$ & 6.5 & 32.2 & 1.4 & 22.8 & 106 & 371 & 524 & 17.09 \\
\hline & $20-40$ & & 16.8 & 0.6 & 26.2 & nd & nd & nd & nd \\
\hline \multirow[t]{3}{*}{ Depositional } & $0-10$ & 6.5 & 9.7 & 0.5 & 19.2 & 163 & 378 & 459 & 7.12 \\
\hline & $10-20$ & 6.1 & 33.3 & 1.2 & 26.8 & 162 & 374 & 464 & 9.17 \\
\hline & $20-40$ & & 6.2 & 0.2 & 26.0 & nd & nd & nd & nd \\
\hline \multicolumn{10}{|l|}{ B204 transect B8 } \\
\hline \multirow[t]{3}{*}{ Crest } & $0-10$ & 5.4 & 46.4 & 1.7 & 27.2 & 183 & 357 & 460 & 11.52 \\
\hline & $10-20$ & 5.3 & 18.4 & 0.7 & 27.1 & 184 & 368 & 449 & 14.15 \\
\hline & $20-40$ & & 10.0 & 0.4 & 27.3 & nd & nd & nd & nd \\
\hline \multirow[t]{3}{*}{ Backslope } & $0-10$ & 5.1 & 31.9 & 1.1 & 28.8 & 145 & 381 & 474 & 8.61 \\
\hline & $10-20$ & 5.1 & 27.5 & 0.8 & 35.7 & 159 & 368 & 473 & 9.74 \\
\hline & $20-28$ & & 19.4 & 0.6 & 34.1 & nd & nd & nd & nd \\
\hline \multirow[t]{3}{*}{ Depositional } & $0-10$ & $\mathrm{nd}^{\mathrm{e}}$ & 167.8 & 5.2 & 32.4 & 113 & 378 & 509 & 3.68 \\
\hline & $10-20$ & & 133.7 & 3.4 & 39.2 & 114 & 395 & 491 & 3.46 \\
\hline & $20-40$ & & 162.3 & 4.0 & 40.7 & nd & nd & nd & nd \\
\hline
\end{tabular}

${ }^{\mathrm{a}}$ Standard error $\leq 0.06$ for analytical replicates; ${ }^{\mathrm{b}}$ standard error $\leq 0.02$ for analytical replicates; ${ }^{\mathrm{c}}$ standard error $\leq 0.7$ for analytical replicates; ${ }^{\mathrm{d}} n=3$ analytical replicates. ${ }^{e}$ Some samples were not measured due to lack of material or prioritizing samples for analysis (indicated by nd for no data).

\subsection{C and N Enrichment ratios}

Enrichment ratios of $\mathrm{C}$ and $\mathrm{N}$ (ER, the ratio of $\mathrm{C}$ or $\mathrm{N}$ concentration in the eroded sediment divided by their concentration in source soil in hillslopes) were highest during years with low precipitation and lowest during high precipitation years (Fig. 6) for both the upper- and lower-elevation watersheds. During years of low precipitation, we observed selective transport of fine material that is high in OM concentration, characteristic of the organic and A horizons. Furthermore, calculated ERs for the crest, backslope or the depositional positions differed substantially in the high-elevation Bull catchments, but not in lower-elevation Providence catchments. The depositional positions in these catchments were highly varied and had points with very high $\mathrm{C}$ and $\mathrm{N}$ concentrations. For high water years 2010 and 211, Bull ER values were more similar between slope positions than in low WY 2007 and 2008. In the low-elevation Providence catchments, ERs were similar across hillslope positions for both $\mathrm{C}$ and $\mathrm{N}$.

\section{Discussion}

Our analyses of sediment transport rates and their composition from the KREW catchments showed a positive relationship between water yield and erosion exports for these catchments that have had experienced minimal disturbance for the past 15 years. In agreement with our hypothesis that sediment yield is closely related to interannual differences in precipitation, we found that total area-normalized annual sediment yield was strongly and positively correlated to annual stream discharge (a proxy for precipitation amount) more than watershed size, slope or soil characteristics. The range and magnitude of exported sediment was comparable to total sediment transport rates in water years 2001-2009 from a subset of these catchments (installed 2002-2004, with the first full set of archived sediments from 2005; Eagan et al., 2007; Hunsaker and Neary, 2012). The range of sediment yield was as much as an order of magnitude greater than the difference in water yield for any given year, supporting a nonlinear response for this ecosystem (Fig. 4). Though small, the sediment yield in low-flow years is not negligible. We observed sediment yield rates on par with a range of other ecosystems. Annual sediment export rates observed in our catchments are more variable than but comparable to average reported rates 
Table 4. Coefficients of variation (standard deviation relative to the mean, expressed in \%) for sediment yield, carbon (C) and nitrogen (N) concentrations, and $\mathrm{C}: \mathrm{N}$ mass ratios averaged across years for each catchment, and averaged across catchments for each water year within the Kings River Experimental Watershed. Archive samples from 2006 were not available for sampling (indicated by no data or nd).

\begin{tabular}{lrrrr}
\hline \multicolumn{5}{c}{ Averaged across all years for each catchment } \\
Catchment & Sediment yield & $\% \mathrm{C}$ & $\% \mathrm{~N}$ & $\mathrm{C}: \mathrm{N}$ \\
\hline D102 & 109.4 & 36.0 & 44.5 & 13.5 \\
P301 & 111.5 & 61.7 & 67.7 & 16.3 \\
P303 & 195.1 & 74.9 & 71.4 & 11.8 \\
P304 & 93.0 & 62.6 & 67.4 & 14.6 \\
B201 & 107.7 & 42.1 & 46.5 & 10.9 \\
B203 & 121.3 & 67.1 & 72.7 & 9.0 \\
B204 & 107.9 & 80.1 & 99.6 & 22.8 \\
T003 & 140.8 & 37.1 & 45.2 & 14.5 \\
\hline Averaged across all catchments for each water year \\
Year & Sediment yield & $\% \mathrm{C}$ & $\% \mathrm{~N}$ & $\mathrm{C}: \mathrm{N}$ \\
\hline 2005 & 69.5 & 40.9 & 46.8 & 22.3 \\
2006 & 92.8 & nd & nd & nd \\
2007 & 115.8 & 36.6 & 36.8 & 13.1 \\
2008 & 165.5 & 46.4 & 44.2 & 14.0 \\
2009 & 78.1 & 46.0 & 44.3 & 12.7 \\
2010 & 68.0 & 66.0 & 64.7 & 13.8 \\
2011 & 135.9 & 89.4 & 84.9 & 18.6 \\
\hline
\end{tabular}

for "stable forest" ecosystems (4-50 $\mathrm{kg} \mathrm{ha}^{-1} \mathrm{yr}^{-1}$, Pimentel and Kounang, 1998), catchments with minimal human disturbance but significant bioturbation $\left(15.6 \mathrm{~kg} \mathrm{ha}^{-1}\right.$, Yoo et al., 2005) and catchments with mixed land use, including forest $\left(60 \mathrm{~kg} \mathrm{ha}^{-1}\right.$, Boix-Fayos et al., 2009). However our study catchments, with little anthropogenic disturbance during or in years prior to our study period, have contemporary sediment export rates far below the average erosion rate on a geologic time scale $\left(750-1110 \mathrm{~kg} \mathrm{ha}^{-1} \mathrm{yr}^{-1}\right)$ for the southern Sierra Nevada (Riebe et al., 2004), suggesting a minimal climatic influence on the long-term sediment erosion rates (Riebe et al., 2001).

We hypothesized that the higher-elevation Bull watersheds would have lower erosion rates than the low-elevation Providence watersheds because of the greater proportion of the precipitation falling as snow at higher elevations, and the greater potential for rain-on-snow events at lower elevations in the Sierras (Bales et al., 2006; Hunsaker et al., 2012). However, we found no significant difference between elevation groups, suggesting that these differences in elevation are not significant drivers of sediment yield for the years we observed. These results suggest that higher elevations, where the rain-snow transition zone is predicted to occur as the climate warms (Klos et al., 2014) in the Sierra, will likely not lead to increased short-term sediment erosion rates from these catchments. However, any associated changes in the in- tensity or amount of precipitation that will alter water yield will likely lead to changes in erosion rates (cf. Fig. 4).

We hypothesized that sediment chemical composition is correlated more with catchment characteristics such as soil composition and slope geometry, which could influence detachment and transport mechanisms, than with precipitation or water yield. However, we found sediment chemical composition was not well correlated with the source catchment, or catchment elevation or size. The one catchment (B201) with an exceptionally low sediment $\mathrm{C}: \mathrm{N}$ ratio could be attributed to the meadow bordering the stream. Sediment chemical composition was far more consistent than sediment yield across catchments as well as years. Sediment chemical composition was most closely correlated with annual water yield. Hence, we reject our hypothesis that sediment chemical composition is dependent on catchment differences more than water yield. Sediment $\mathrm{C}$ and $\mathrm{N}$ concentrations, and the $\mathrm{C}: \mathrm{N}$ ratio were weakly correlated with water yield, but the correlations had low predictive values, suggesting other factors may be more important. With relatively consistent $\mathrm{C}$ and $\mathrm{N}$ concentrations, these results suggest that the total amount of OM exported from the Sierra Nevada depends largely on total sediment yield. The average annual sediment yield resulted in the export of $0.2-4.4 \mathrm{~kg} \mathrm{Cha}^{-1} \mathrm{yr}^{-1}$, compared to the estimated $\mathrm{C}$ stock in these soils of between 80000 and $111000 \mathrm{~kg} \mathrm{Cha}^{-1}$ in the top meter of soil (Johnson et al., 2011). It is a very small flux compared to the overall carbon pool. As stated earlier, there is discordance between these years and the geologic-scale erosion rate, which may indicate isolated erosion events which should be considered for their impact on $\mathrm{C}$ movement and the net $\mathrm{C}$ balance.

The soils in the two elevation watershed groups (i.e., Providence and Bull watersheds) were consistent, and perhaps too consistent to expect differences in sediment chemical composition between the elevation groups based on lithology or soil composition. Few soil characteristics show an elevational pattern (Johnson et al., 2011); however, there were differences between the hillslope locations, particularly the depositional locations compared to the other locations. Given the differences among hillslope locations, contributions from upland sediment sources may lead to more variation in sediment composition than elevational differences in these and similar regions of the western Sierra Nevada.

Hillslope gradient, especially in areas adjacent to streams, plays a role in sediment yield (Litschert and MacDonald, 2009). The three catchments with the highest sediment yields (T003, P304 and D102) had steep (frequently greater than $25^{\circ}$ ) slopes near the stream, while other catchments have more moderate $\left(<15^{\circ}\right)$ slopes in those areas (Fig. 7). The steepest slopes adjacent to the stream in catchment D102 are made up of exposed bedrock, which may explain why the D102 catchment did not yield the highest sediment even though it has steep slopes adjacent to streams.

Two catchments, T003 and P304, had exceptionally high sediment yield. High sediment yield from the T003 catch- 


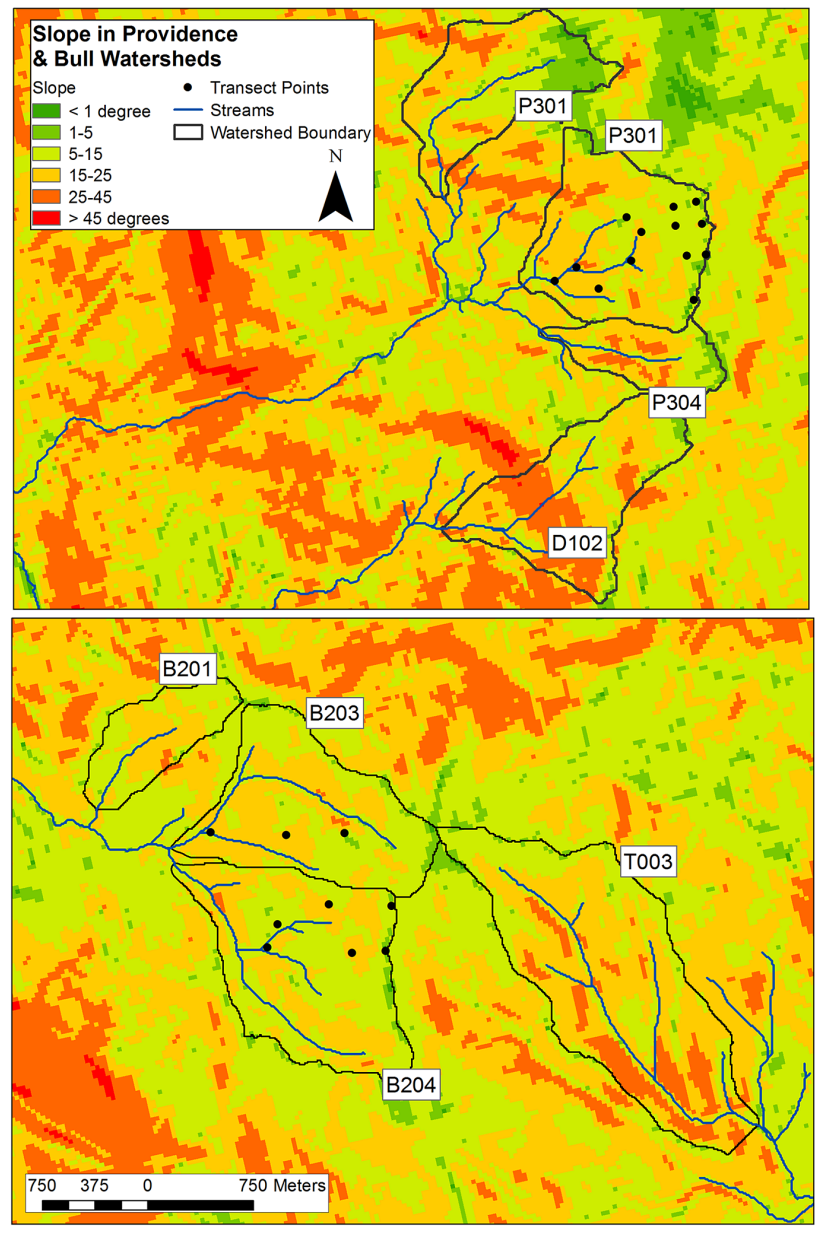

Figure 7. Slopes in the eight catchments are moderately steep as shown by a weighted scale $\left(<1^{\circ}\right.$ dark green; $1-5^{\circ}$ medium green; $5-15^{\circ}$ chartreuse; $15-25^{\circ}$ light orange; $25-45^{\circ}$ dark orange; $>45^{\circ}$ red). Flat areas in crest and depositional locations are very small. Slope values calculated from a $10 \mathrm{~m}$ digital elevation model. Mean annual sediment export is given for water years 2005-2011.

ment was especially surprising because this catchment has never been impacted by logging or roads (Hunsaker and Neary, 2012). Compared to companion catchments, T003 and P304 have long, narrow geometries and eroded soil travels shorter distance to travel to streams (Hunsaker and Neary, 2012). Several other factors, including low rock fraction in topsoil, and low proportion of exposed granite, and ongoing down-cutting of channels in P304 have previously been suggested to explain the P304 sediment response (for more in-depth discussion on these factors see Hunsaker and Neary, 2012; Eagan et al., 2007; Martin 2009).

Multiple reasons may explain the inverse relationship between $\mathrm{C}$ and $\mathrm{N}$ concentrations and sediment yield, including preferential transport, differences in the source of the material, or sampling basin capture efficiency. Water-based surface erosion processes (for example sheet erosion) preferentially mobilize fine particles with their associated OM over mineral soils from deeper in the soil profile, resulting in $\mathrm{C}$ and/or $\mathrm{N}$ enrichment in eroded sediments (Nadeu et al., 2012). We found enrichment of OM in sediment compared to soils in years with low precipitation for both elevation groups (cf. Fig. 6), which could support preferential transport of surficial organic material to streams during these periods.

Another possible reason for the inverse relationship between $\mathrm{C}$ and $\mathrm{N}$ concentrations and sediment yield is that erosive processes detach and transport OM-poor material from different sources or deeper in the soil profile than in low precipitation years. Erosion processes that impact deeper layers (including gullies, mass wasting or bank erosion) mobilize material with lower OM concentrations as well as waterstable aggregates (Nadeu et al., 2012). However, geomorphic features which increase connectivity in the catchments (e.g., gullies or convex hillslopes) are present but not common in our study catchments (Stafford, 2011). Stafford (2011) reported that water-driven surface erosion from or near roads (OM-poor sources) in these catchments to be orders of magnitude higher than erosion on vegetated hillslopes. In two of the five years, hillslope sediment fences captured no measureable sediment; however in other years (2005, 2006 and 2008), mean hillslope sediment erosion rates ranged from 6 to $32.9 \mathrm{~kg} \mathrm{ha}^{-1} \mathrm{yr}^{-1}$ (Stafford, 2011), which is comparable to sediment exported from these catchments.

Changes in the trapping efficiency of the sediment basins with changes in water yield is another possibility for the inverse relationship between $\mathrm{C}$ and $\mathrm{N}$ concentrations and sediment yield. For instance, lower efficiency of capture of low density, high $\mathrm{C}$ and $\mathrm{N}$ concentration material (e.g., free organics) during high discharges would have lead to low $\mathrm{C}$ and $\mathrm{N}$ concentrations in captured sediment in these high water yield years. In a review of several studies, Verstraeten and Poesen (2000) found trapping efficiency rates of sediment mass in individual events can be as low as $50 \%$, especially in high discharge events. The trapping efficiency of the sediment basins was not measured in this project due to labor and budget constraints. However, considering the nature of soils and SOM in our study catchments, and the discharge events recorded, we can assume that most of the $C$ laterally distributed from the hillslopes is likely trapped in the basins. It is likely that some $\mathrm{C}$ existing as free organic particles and $\mathrm{C}$ associated with very small mineral particles (that remain in suspension the longest) could be transported further and at least partially contribute to the inverse relationship discussed above. However, the loss of $\mathrm{C}$ as dissolved and suspended particulate OM is likely to be, at least partially, compensated by input of $\mathrm{C}$ from vegetation growing above the sediment basins.

\section{Implications for predicting fate of eroded $\mathrm{OM}$ in upland forest ecosystems}

The process of soil OM erosion in upland forest ecosystems, and its contribution to the erosion-induced $\mathrm{C}$ sink is fun- 
damentally different than those in cultivated and grassland ecosystems. These montane Sierra Nevada catchments have higher surficial concentrations of C and N (Dahlgren et al., 1997; Johnson et al., 1997) and steeper slopes (cf. Fig. 7) than agroecosystems (Quine and Van Oost, 2007; Van Oost et al., 2007; Berhe et al., 2007), which could contribute to export of OM-rich material without allowing for significant decomposition during transport. If deposited within the source or adjacent catchments, the OM can be protected through various mechanisms with burial (Berhe and Kleber, 2013) or through chemical associations that OM forms with soil minerals during or after transport, leading to stabilization of the eroded OM (VandenBygaart et al., 2012, 2015). In the KREW catchments, there is potential for $\mathrm{C}$ loss during transport as well as stabilization through various mechanisms compared to other non-montane ecosystems (Stacy, 2012). These forest ecosystems had low erosion rates, with only a small fraction of the total $\mathrm{C}$ pool subject to erosion. Furthermore, the OM-rich nature of eroded sediment raises important questions about the fate of the eroded OM during and after erosional transport. If a large fraction of the SOM eroded from forest ecosystems is lost during transport or after deposition, the eroded organic matter would not be preserved. At least under contemporary rates of erosion, we did not find evidence that erosion in these forest ecosystems can constitute a significant $\mathrm{C}$ sink. Changing climate could potentially alter this balance through changes to water yield, through vegetative shifts to shrubland or grassland, or through the increased risk of fire. The ultimate fate of this eroded $\mathrm{C}$ and $\mathrm{N}$ and its contribution towards erosion-induced $\mathrm{C}$ sequestration will depend on how far the material is transported and rates of OM decomposition after deposition (Berhe and Kleber, 2013; Berhe et al., 2012b).

\section{Conclusion}

Overall, our findings show that there was no consistent, statistically significant difference in erosion rates of sediment, $\mathrm{C}$ or $\mathrm{N}$ from rain- versus snow-dominated headwater catchments in the southern Sierra Nevada. Water yield does not strongly moderate sediment $\mathrm{C}$ and $\mathrm{N}$ concentrations, but it is a major driver of total $\mathrm{C}$ and $\mathrm{N}$ export from these catchments because of the correlation with sediment yield. Enrichment in OM supports the contribution of surficial sources and the dominance of sheet erosion over other erosional processes. Differences in enrichment ratios of $\mathrm{C}$ and $\mathrm{N}$ in captured sediments may be driven by higher rates of eroded sediment during wetter years or preferential loss from the sediment basins during high stream discharge. Including precipitationevent-based sampling and quantification of trap efficiency in each catchment would help improve quantification of sediment and associated OM export rates for such upland forest catchments. Based on our results, we conclude that changes in the amount of precipitation but not the timing or precipita- tion form will have important implications for both the nature and amount of OM that is eroded from forested ecosystems, and for whether erosion in forested catchments can induce a significant sink for atmospheric $\mathrm{CO}_{2}$.

Acknowledgements. This research was conducted in the Kings River Experimental Watersheds (KREW), which was established and is managed for US Forest Service Pacific Research Station. The KREW study was implemented using funds from the National Fire Plan of the USDA Forest Service. Additional funding for this work was provided from the US Forest Service, the Southern Sierra Critical Zone Observatory Project from the National Science Foundation (EAR-0725097). NSF award to A. A. Berhe, S. C. Hart and D. W. Johnson (EAR-1147977), and a Graduate Research Council grant from the University of California, Merced. We thank Matthew McClintock, members of the Berhe and Hart labs at UC Merced, researchers within the Southern Sierra Critical Zone Observatory (SSCZO), and the US Forest Service crews from the Pacific Southwest Research Station for assistance in the field and in lab portions of this work.

Edited by: D. Obrist

\section{References}

Bales, R. C., Molotch, N. P., Painter, T. H., Dettinger, M. D., Rice, R., and Dozier, J.: Mountain hydrology of the western United States, Water Resour. Res., 42, W08432, doi:10.1029/2005WR004387, 2006.

Bales, R. C., Hopmans, J. W., O’Geen, A. T., Meadows, M., Hartsough, P. C., Kirchner, P., Hunsaker, C. T., and Beaudette, D.: Soil moisture response to snowmelt and rainfall in a Sierra Nevada mixed-conifer forest, Vadose Zone J., 10, 786-799, 2011.

Berhe, A. A.: Decomposition of organic substrates at eroding vs. depositional landform positions, Plant Soil, 350, 261-280, doi:10.1007/s11104-011-0902-z, 2012.

Berhe, A. A. and Kleber, M.: Erosion, deposition, and the persistence of soil organic matter: mechanistic considerations and problems with terminology, Earth Surf. Proc. Land., 38, 908912, doi:10.1002/esp.3408, 2013.

Berhe, A. A., Harte, J., Harden, J. W., and Torn, M. S.: The Significance of Erosion-Induced Terrestrial Carbon Sink, BioScience, 57, 337-346, 2007.

Berhe, A. A., Harden, J. W., Torn, M. S., and Harte, J.: Linking soil organic matter dynamics and erosion-induced terrestrial carbon sequestration at different landform positions, J. Geophys. Res., 113, G04039, doi:10.1029/2008jg000751, 2008.

Berhe, A. A., Harden, J., Torn, M., Kleber, M., Burton, S., and Harte, J.: Persistence of Soil Organic Matter in Eroding vs. Depositional Landform Positions, J. Geophys. Res., 117, G02019, doi:10.1029/2011JG001790, 2012a.

Berhe, A. A., Suttle, K. B., Burton, S. D., and Banfield, J. F.: Contingency in the Direction and Mechanics of Soil Organic Matter Responses to Increased Rainfall, Plant Soil, 358, 371-383, doi:10.1007/s11104-011-0902-z, 2012b. 
Berhe, A. A., Torn, M. S., and Harden, J. W.: Soil nitrogen storage and stabilization in eroding landscapes, Biogeochemistry, in review, 2015.

Boix-Fayos, C., de Vente, J., Albaladejo, J., and Martínez-Mena, M.: Soil carbon erosion and stock as affected by land use changes at the catchment scale in Mediterranean ecosystems, Agr. Ecosyst. Environ., 133, 75-85, 2009.

Boix-Fayos, C., Nadeu, E., Quiñonero, J. M., Martínez-Mena, M., Almagro, M., and de Vente, J.: Sediment flow paths and associated organic carbon dynamics across a Mediterranean catchment, Hydrol. Earth Syst. Sci., 19, 1209-1223, doi:10.5194/hess-191209-2015, 2015.

Brunauer, S., Emmett, P. H., and Teller, E.: Adsorption of gases in multimolecular layers, J. Am. Chem. Soc., 60, 309-319, 1938.

Burnham, K. P. and Anderson, D. R.: Model Selection and Multimodel Inference: A Practical Information-Theoretic Approach, Springer-Verlag, New York, ISBN 0-387-95364-7, 2002.

Chappell, A., Sanderman, J., Thomas, M., Read, A., and Leslie, C.: The dynamics of soil redistribution and the implications for soil organic carbon accounting in agricultural south-eastern Australia, Glob. Change Biol., 18, 2081-2088, 2012.

Dahlgren, R., Boettinger, J., Huntington, G., and Amundson, R.: Soil development along an elevational transect in the western Sierra Nevada, California, Geoderma, 78, 207-236, 1997.

Eagan, S. M., Hunsaker, C. T., Dolanc, C. R., Lynch, M. E., and Johnson, C. R.: Discharge and Sediment Loads at the Kings River Experimental Forest in the Southern Sierra Nevada of California, in: Advancing the Fundamental Sciences: Proceedings of the Forest Service National Earth Sciences Conference, San Diego, CA, 18-22 October 2004, PNW-GTR-689, Portland, OR: US Department of Agriculture, Forest Service, Pacific Northwest Research Station, edited by: Furniss, M., Clifton, C., and Ronnenberg, K., 2007.

Hancock, G. R.: Hillslope and catchment scale soil organic carbon concentration: An assessment of the role of geomorphology and soil erosion in an undisturbed environment, Geoderma, 155, 3645, 2010.

Harden, J. W., Sharpe, J. M., Parton, W. J., Ojima, D. S., Fries, T. L., Huntington, T. G., and Dabney, S. M.: Dynamic replacement and loss of soil carbon on eroding cropland, Global Biogeochem. Cy., 13, 885-901, 1999.

Harden, J. W., Berhe, A. A., Torn, M., Harte, J., Liu, S., and Stallard, R. F.: Soil Erosion: Data Say C Sink, Science, 320, 178-179, doi:10.1126/science.320.5873.178, 2008.

Hunsaker, C. T. and Neary, D. G.: Sediment loads and erosion in forest headwater streams of the Sierra Nevada, California, in: Revisiting Experimental Catchment Studies in Forest Hydrology, Proceedings of a Workshop held during the XXV IUGG General Assembly in Melbourne, June-July 2011, IAHS Publ. 353, 2012.

Hunsaker, C. T., Adair, J., Auman, J., Weidich, K., and Whitaker, T.: Kings River Experimental Watershed research study plan, available at: http://www.fs.fed.us/psw/topics/water/kingsriver/ documents/miscellaneous/KREW_Study_Plan_Sep2007.pdf (last access: 28 April 2015), 2007.

Hunsaker, C. T., Whitaker, T. W., and Bales, R. C.: Snowmelt Runoff and Water Yield Along Elevation and Temperature Gradients in California's Southern Sierra Nevada, J. Am. Water Resour. As., 48, 667-678, doi:10.1111/j.1752-1688.2012.00641.x, 2012.
IPCC: Climate change: The physical science basis, Contribution of Working Group I to the Fourth Assessment Report of the Intergovernmental Panel on Climate Change, edited by: Solomon, S., Qin, D., Manning, M., Chen, Z., Marquis, M., Averyt, K. B., Tignor, M., and Miller, H. L., Cambridge University Press, Cambridge, United Kingdom and New York, USA, 2007.

Johnson, D., Susfalk, R., and Dahlgren, R.: Nutrient fluxes in forests of the eastern Sierra Nevada mountains, United States of America, Global Biogeochem. Cy., 11, 673-681, 1997.

Johnson, D., Hunsaker, C., Glass, D., and Rau, B.: Carbon and nutrient contents in soils from the Kings River Experimental Watersheds, Sierra Nevada Mountains, California, Geoderma, 160, 490-502, 2011.

Johnson, D. W., Hunsaker, C. T., and D. E. Todd Jr.: Spatial variations in forest soils at two scales: Comparisons of King's River Watersheds, California and Walker Branch Watershed, Tennessee, Biogeomon 2012: The 7th International Symposium on Ecosystem Behavior, Northport, ME, USA, 2012.

Kirkby, M. J.: Distance, time and scale in soil erosion processes, Earth Surf. Proc. Land., 35, 1621-1623, doi:10.1002/esp.2063, 2010.

Klos, P. Z., Link, T. E., and Abatzoglou, J. T.: Extent of the rainsnow transition zone in the western US under historic and projected climate, Geophys. Res. Lett., 41, 4560-4568, 2014.

Litschert, S. and MacDonald, L.: Frequency and characteristics of sediment delivery pathways from forest harvest units to streams, Forest Ecol. Manag., 259, 143-150, 2009.

Martin, S. E.: Comparison of in-stream sediment sources and assessment of a bank migration model for headwater catchments in the Central Sierra Nevada, California, M.S., Environmental Systems, University of California, Merced, 2009.

Nadeu, E., de Vente, J., Martínez-Mena, M., and Boix-Fayos, C.: Exploring particle size distribution and organic carbon pools mobilized by different erosion processes at the catchment scale, J. Soil. Sediment., 11, 667-678, 2011.

Nadeu, E., Berhe, A. A., de Vente, J., and Boix-Fayos, C.: Erosion, deposition and replacement of soil organic carbon in Mediterranean catchments: a geomorphological, isotopic and land use change approach, Biogeosciences, 9, 1099-1111, doi:10.5194/bg-9-1099-2012, 2012.

Parfitt, R. L., Baisden, W. T., Ross, C. W., and Rosser, B. J.: Influence of Erosion and Deposition on Carbon and Nitrogen Accumulation in Resampled Steepland Soils Under Pasture in New Zealand, Geoderma, 19, 154-159, 2013.

Pimentel, D. and Kounang, N.: Ecology of soil erosion in ecosystems, Ecosystems, 1, 416-426, 1998.

Quine, T. A. and Van Oost, K.: Quantifying carbon sequestration as a result of soil erosion and deposition: retrospective assessment using caesium-137 and carbon inventories, Glob. Change Biol., 13, 2610-2625, doi:10.1111/j.1365-2486.2007.01457.x, 2007.

Quinton, J. N., Govers, G., Van Oost, K., and Bardgett, R. D.: The impact of agricultural soil erosion on biogeochemical cycling, Nat. Geosci., 3, 311-314, 2010.

Riebe, C. S., Kirchner, J. W., Granger, D. E., and Finkel, R. C.: Strong tectonic and weak climatic control of long-term chemical weathering rates, Geology, 29, 511-514, 2001.

Riebe, C. S., Kirchner, J. W., and Finkel, R. C.: Erosional and climatic effects on long-term chemical weathering rates in granitic 
landscapes spanning diverse climate regimes, Earth Planet. Sc. Lett., 224, 547-562, 2004.

Rumpel, C. and Kogel-Knabner, I.: Deep soil organic matter-a key but poorly understood component of terrestrial C cycle, Plant Soil, 338, 143-158, 2011.

Rumpel, C., Chaplot, V., Ciais, P., Chabbi, A., Bouahom, B., and Valentin, C.: Composition changes of eroded carbon at different spatial scales in a tropical watershed suggest enrichment of degraded material during transport, Biogeosciences, 11, 32993305, doi:10.5194/bg-11-3299-2014, 2014.

Sanderman, J. and Chappell, A.: Uncertainty in soil carbon accounting due to unrecognized soil erosion, Glob. Change Biol., 19, 264-272, 2013.

Stacy, E. M.: Composition and stabilization mechanisms of organic matter in soils and sediments eroded from granitic, low-order catchments in the Sierra Nevada, California, M.S., Environmental Systems, University of California, Merced, 2012.

Stafford, A. K.: Sediment Production and Delivery From Hillslopes and Forest Roads in the Southern Sierra Nevada, California, M.S., Department of Forest, Rangeland, and Watershed Stewardship, Colorado State University, 197 pp., 2011.

Stallard, R.: Terrestrial sedimentation and the carbon cycle: Coupling weathering and erosion to carbon burial, Global Biogeochem. Cy., 12, 231-257, 1998.

Vandenbygaart, A. J., Kroetsch, D., Gregorich, E. G., and Lobb, D.: Soil C erosion and burial in cropland, Glob. Change Biol., 18, 1441-1452, 2012.

Vandenbygaart, A. J., Gregorich, E. G., and Helgason, B. L.: Cropland $\mathrm{C}$ erosion and burial: Is buried soil organic matter biodegradable?, Geoderma, 239, 240-249, 2015.
Van Oost, K., Govers, G., De Alba, S., and Quine, T. A.: Tillage erosion: a review of controlling factors and implications for soil quality, Prog. Phys. Geog., 30, 443-466, doi:10.1191/0309133306pp487ra, 2006.

Van Oost, K., Quine, T., Govers, G., De Gryze, S., Six, J., Harden, J., Ritchie, J., McCarty, G., Heckrath, G., and Kosmas, C.: The impact of agricultural soil erosion on the global carbon cycle, Science, 318, 626-629, 2007.

Verstraeten, G. and Poesen, J.: Estimating trap efficiency of small reservoirs and ponds: methods and implications for the assessment of sediment yield, Prog. Phys. Geog., 24, 219-251, 2000.

Wang, Z., Van Oost, K., Lang, A., Quine, T., Clymans, W., Merckx, R., Notebaert, B., and Govers, G.: The fate of buried organic carbon in colluvial soils: a long-term perspective, Biogeosciences, 11, 873-883, doi:10.5194/bg-11-873-2014, 2014.

Wiaux, F., Cornelis, J. T., Cao, W., Vanclooster, M., and Van Oost, K.: Combined effect of geomorphic and pedogenic processes on the distribution of soil organic carbon quality along an eroding hillslope on loess soil, Geoderma, 216, 36-47, doi:10.1016/j.geoderma.2013.10.013, 2013.

Yoo, K., Amundson, R., Heimsath, A., and Dietrich, W.: Erosion of upland hillslope soil organic carbon: Coupling field measurements with a sediment transport model, Global Biogeochem. Cy., 19, GB3003, doi:10.1029/2004GB002271, 2005.

Yoo, K., Amundson, R., Heimsath, A. M., and Dietrich, W. E.: Spatial patterns of soil organic carbon on hillslopes: Integrating geomorphic processes and the biological C cycle, Geoderma, 130, 47-65, 2006. 